\title{
SEVERE ACCIDENT MANAGEMENT CONCEPT OF THE VVER-1000 AND THE JUSTIFICATION OF CORIUM RETENTION IN A CRUCIBLE-TYPE CORE CATCHER
}

\author{
VLADIMIR BENZIANOVICH KHABENSKY, VLADIMIR SEMENOVICH GRANOVSKY, SEVOSTIAN \\ VICTOROVICH BECHTA* and VICTOR VLADIMIROVICH GUSAROV ${ }^{1}$ \\ Alexandrov Scientific Research Institute of Technology (NITI), Sosnovy Bor, Russia \\ ${ }^{1}$ St. Petersburg State Electrotechnical University, St. Petersburg, Russia \\ "Corresponding author. E-mail : bechta@sbor.spb.su
}

Received April 14, 2009

First ex-vessel core catcher has been applied to the practical design of NPPs with VVER-1000 reactors built in China (Tyanvan) and India (Kudankulam) for severe accident management (SAM) and mitigation of SA consequences. The paper presents the concept and basic design of this crucible-type core catcher as well as an evaluation of its efficiency. The important role of oxidic sacrificial material is discussed. Insight into the behaviour of the molten pool, which forms in the catcher after core relocation from the reactor vessel, is provided. It is shown that heat loads on the water-cooled vessel walls are kept within acceptable limits and that the necessary margins for departure from nucleate boiling (DNB) and of vessel failure caused by thermo-mechanical stress are satisfactorily provided for.

KEYWORDS : VVER Reactor, Severe Accident, Core Melting, Ex-vessel Core Catcher, Melt Retention

\section{INTRODUCTION}

Modern NPP designs require a device for core melt localization within the containment, a key element of SAM. Several concepts of molten core immobilization have been developed and implemented.

First among them is the in-vessel corium retention (IVR) in combination with passive cooling of the external vessel surface without departure from nucleate boiling (DNB). This concept has been implemented at mediumpower NPPs with VVER-440 (Loviisa, Finland) [1], AP600 (Westinghouse, USA) [2] and VVER-640 (SPbAEP, Russia) [3] designs, as well as for large-power NPPs with AP-1000 (Westinghouse, USA) [4] and BWR-1000 (Framatome, France) reactors [5].

Although this technical solution is quite efficient and apparently simple, it has a limitation. Due to a lack of knowledge and substantial modeling uncertainty of certain phenomena, in particularly the molten pool formation dynamics and physicochemical behaviour are not well understood. For this reason, considerable margin is required for heat flux from the vessel external surface in comparison with the critical heat flux of water nucleate boiling. At present, this guaranteed margin in compliance with conservative requirements is possible only for small- and average-capacity reactors. IVR application for largecapacity reactors $\left(\mathrm{N}_{\mathrm{el}}>1000 \mathrm{MW}\right)$ does not achieve an appropriate safety margin. Consequently, considerable additional experimental studies and refined accuracy of related numerical codes are necessary for this.

Other concepts under development at present deal with the ex-vessel corium retention (EVR). There are several R\&D directions in this regard. The least developed concept is that accepted in Sweden for BWR reactors [6] In accordance with this approach, the molten core releases into the under-reactor cavity of a concrete pit filled with water. This concept of core-catching and immobilization has not found wide acknowledgement due to steam explosion danger during FCI.

At present two EVR concepts have been fully developed and applied:

- a crucible-type catcher developed for Russian NPPs with a VVER-1000 reactor [7-9];

- catcher with melt spreading developed for the European

EPR reactor [10].

In the design of the EPR catcher after reactor vessel failure, corium is spread across a large-area horizontal surface and cooled by top flooding together with simultaneous cooling of the bottom of the core melt. New EPR NPPs having this ex-vessel core catcher are under construction in Finland and France; similar design has also been accepted for implementation in USA.

This concept has the following specific features [10]:

1. After reactor vessel failure, the molten core does not 
spread into the catcher immediately; first it is conditioned in a pre-catcher located in the reactor pit. The precatcher contains sacrificial material (SM), which has a special composition of fusible oxides. The presence of SM secures melt retention for a period exceeding the time of melt relocation from the vessel. During this period the decay heat of the relocated molten core is spent on SM melting and dissolution; note that the initial melt characteristics change in a predetermined way. The calculated SM mass immobilizes the melt in the pre-catcher for approx. 1 hour. The melt then penetrates through steel plug of the pre-catcher and flows into the catcher via a sloping channel.

2. The pre-catcher is designed to quench thermomechanical impact; if the reactor bottom breaks off, it buffers the influence of different severe accident scenarios on the melt conditions before the melt enters the spreading compartment. The reduction of the liquidus and solidus temperatures and the viscosity of the melt by the dissolution of sacrificial oxides increases corium superheating and contributes to better spreading; metallic zirconium is oxidized in the melt during its interaction with SM.

The melt relocated into the catcher is spread as a relatively thin layer across a rather large horizontal surface covered by a zirconia-based protective material. This refractory material is located under a metallic layer and a layer of sacrificial material so as to eliminate contact between the protective material and the oxidic part of the molten corium. The melt is cooled by flooding and by decay heat removal from the bottom. In the EPR design, cooling water is directly supplied onto the corium melt surface.

An advantage of the EPR catcher is fast melt solidification. Its disadvantages, meanwhile, are the large area required for the core catcher, a buildup of peak pressure in containment at melt cooling, and a non-compact structure of solidified corium. The efficiency of the EPR EVR concept has been proved by extensive programs of experimental and analytical activities in different European organizations.

The concept of the EVR with a crucible-type catcher was initially developed for the VVER-1000 and implemented within the Tyanvan and Kudankulam projects in China and India. This concept combines the IVR approaches, i.e. passive water cooling of the metallic catcher vessel (crucible), which has the joint function of an immobilization barrier, and the EPR solution, i.e. use of sacrificial materials. This combination enables, on one hand, to reduce the heat flux from the melt to the cooled vessel surface to a level corresponding to the IVR conditions in a medium-capacity reactor, and, on the other hand, to avoid construction of a large-area catcher necessary for melt spreading.

The crucible-type catcher option incorporates the results of previous studies carried out within the IVR concept development.

The following section provides a more detailed explanation of the efficiency of a crucible-type core catcher for NPPs with VVER-1000 reactors.

\section{SEVERE ACCIDENT MANAGEMENT CONCEPT AND A CRUCIBLE-TYPE CORE CATCHER}

The concept and basic design of a crucible-type core catcher are described in detail in [8-9]; the scheme of the catcher is presented in Fig. $1(\mathrm{a}, \mathrm{b})$.

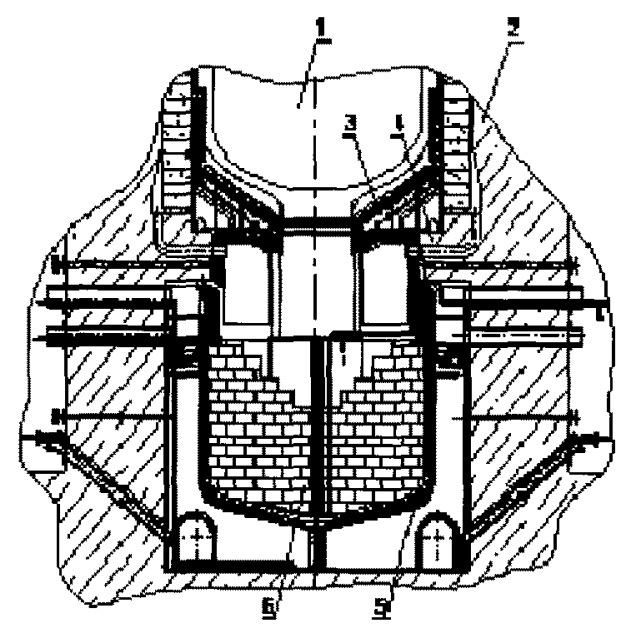

a)

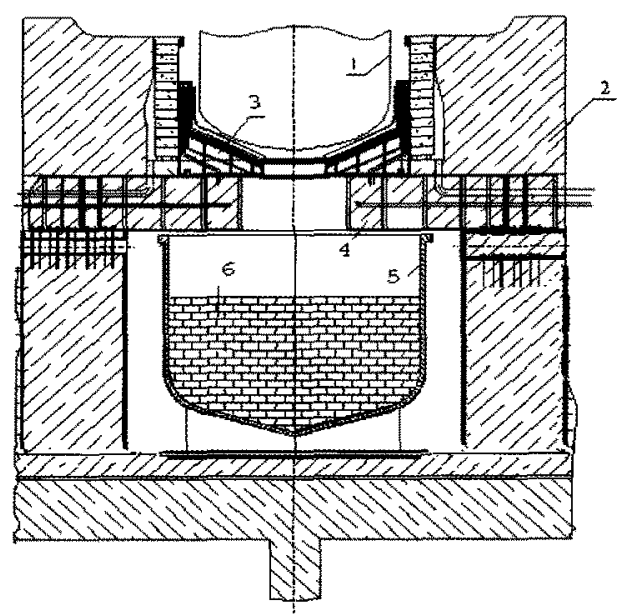

b)

Fig. 1. Principal Layout of Core Catcher of Tyanwan (a) and Kudankulam NPPs (b)

(1 - Reactor Pressure Vessel (RPV); 2 - Reactor Cavity; 3 - Lower Plate; 4 - Cantilever Girder; 5 - Core Catcher Vessel; 6 - SM) 
The melt is immobilized within a water-cooled steel vessel, the main component of the catcher. The vessel has vertical walls and a conical bottom with an inclination angle of $12-16^{\circ}$. This inclination increases the minimum critical heat flux during the bottom cooling by stagnant water boiling in comparison with a semi-elliptical or semi-spherical bottom [11-13].

The internal volume of the catcher vessel is partially filled with sacrificial material, which contains oxidic components and steel (OSM and SSM). The OSM is placed into steel cassettes; they form a large-cell honeycomb structure, which facilitates fast corium spreading and increases the SM-corium interaction surface. The catcher capacity is sufficient to accommodate the whole mass of the anticipated core melt and to provide heat transfer from the molten pool through the vessel walls and bottom to the cooling water. The heat from the upper surface of the melt is temporally removed by radiation, and, later, by the water covering the melt surface.

Steel sheeting on the vessel top aperture prevents water ingress into the catcher before the melt relocation. This considerably reduces the probability of steam explosions; if water enters the vessel together with the melt, the honeycomb internals of the catcher efficiently eliminate the explosion hazard.

During the first 1-3 hours after vessel failure, the structural elements of the reactor pit, the uncooled part of the catcher vessel, and load bearing structures are protected from the radiant heat flux from the melt surface by insulation panels fabricated from a special concrete containing iron and aluminum oxides and Portland cement. After a delay time calculated for the given specific design, the melt is flooded by water (at a fixed flow rate) for the long-term protection of the structures and catcher components.

The SSM \& OSM are key components in the crucibletype core catcher concept. The SSM (construction material in cassettes and in-catcher structures) is used for reducing the temperature of the metallic melt coming from the reactor vessel. The OSM has a light oxide composition and must meet the following requirements:

1. During normal operation of the reactor the OSM is expected to possess the following properties: longterm mechanical strength to guarantee its reliable performance during 60 years, and the capacity to resist significant activation by neutron flux.

2. During its interaction with a high-temperature molten core the OSM has to perform a number of functions described in detail below.

3. After melt solidification and during cleanup operations the OSM should provide for the long-term stability of solidified corium in spite of ongoing radiochemical and chemical processes caused by corium interaction with borated water, steam, and air, as well as low leaching rates of the fission products.

4. During the NPP decommissioning after accident-free service, easy and safe disassembly of the structure and inexpensive disposal of the material should be possible.

It should be noted that requirements 1,3 , and 4 are met by the crucible design of the catcher itself, which provides a compact placement of SM and corium solidified inside a fixed vessel, a small surface of ingot contact with water and air, and a substantially smaller neutron flux from the reactor vessel to the SM due to absorption by the thick concrete slab between them.

As mentioned above, OSMs are designed to meet a number of requirements of group 2, which are critical for effective performance of the crucible-type core catcher.

Let us consider functional requirements first. They are as follows:

- reduction of uncertainties caused by different accident progression scenarios, which are characterized by different corium melt temperature, compositions, and scenarios of corium relocation into the catcher;

- $\mathrm{Zr}$, $\mathrm{U}$, and $\mathrm{Cr}$ oxidation in the oxidic and metallic melts during their interaction with OSM to minimize hydrogen release during the melt interaction with steam and water;

- restriction of relocated melt heatup during the $\mathrm{Zr}, \mathrm{U}$, and Cr oxidation using the SM cooling capacity;

- considerable reduction of the melt-catcher wall heat flux by increasing the oxidic melt volume and corresponding increase of the heat transfer surface by OSM dissolution without liquid immiscibility in the oxidic fraction of the relocated core;

- guaranteed inversion of the metallic and oxidic corium liquid layers in the catcher to avoid heat flux focusing on the vessel wall in the zone of the overlying steel layer, as well as avoidance of steam explosions and restriction of hydrogen generation caused by steammetal reactions after melt top flooding;

- elimination of the secondary criticality at any possible configuration of debris at any water to uranium ratio (to be conservative, pure unborated water is considered); - reduced release of gases, aerosols, and fission products. The OSM choice is a challenging and complex task. The functional requirements facilitate formulation of the requirements for its components and help in drawing up a list of candidates for the final decision.

Requirements for the OSM composition are as follows:

- The inversion of oxidic and metallic parts in the core catcher stipulates a low density of OSM components $\left(<6 \mathrm{~g} / \mathrm{cm}^{2}\right)$ and their dissolution in the relocated oxidic melt without a miscibility gap (MG) to form a homogeneous molten solution.

- The reduction of heat flux from oxidic melt to the catcher wall by increasing the volume of oxidic melt (and, consequently, by increasing the heat transfer surface) is also provided by complete OSM dissolution in the melt, without MG. To reduce the temperature of the melt produced by the OSM interaction with the 
relocated core, the OSM components are to have a large heat capacity and high latent heat of fusion, so that the integral heat effect would not be substantially exothermal.

- For accelerated interaction between the melt and OSM followed by the inversion of metallic and oxidic parts, the OSM oxides interacting with the molten core are to form low-temperature eutectic-type systems.

- The complete oxidation of metallic $\mathrm{Zr}, \mathrm{U}$, and $\mathrm{Cr}$ and limitation of hydrogen generation require the presence of components with high oxidative capacity.

- To suppress aerosol and FP release, the OSM should not contain substances with a high partial pressure in a certain temperature range.

- In order to reduce the release of incondensable gases and aerosols from the core melt, corium interaction with OSM has to be accompanied by a minimum gas generation.

- To guarantee the core melt subcriticality in the catcher the OSM is to contain an oxide of absorber material, which is uniformly distributed in the oxidic corium melt and co-crystallizes with uranium and plutonium oxides.

- OSM has to possess long-term mechanical strength, chemical inertness to atmospheric influences, and be freely available in the natural environment and comparatively cheap.

The multiple, equally-important, but sometimes contradictory requirements for the OSM mean that an optimal solution can be provided only by a multicomponent system, the qualitative and quantitative composition of which should meet the above-listed requirements in the best possible way. It is assumed that the core melt has two liquids (metallic and oxidic), and each of them has its own interaction pattern with the OSM and SSM. The final OSM composition was chosen using the criteria of functional efficiency and technological and economic feasibility.

Detailed explanations of the OSM development methodology can be found in [14-18]; in these works, theoretical, numerical, and expert analyses of alternative materials were made, followed by experimental determination of their properties and studies of their interactions with molten corium. These research activities resulted in the selection of $\mathrm{Fe}_{2} \mathrm{O}_{3}$ and $\mathrm{Al}_{2} \mathrm{O}_{3}$ as main components with the addition of $\mathrm{Gd}_{2} \mathrm{O}_{3}$ as a neutron absorber and small quantities of other technological admixtures. Experimental studies were conducted to determine the optimal concentrations of components for the best possible thermodynamical, thermophysical, mechanical, and other characteristics. The final OSM composition is approx. $70 \% \mathrm{Fe}_{2} \mathrm{O}_{3}$, approx. $30 \% \mathrm{Al}_{2} \mathrm{O}_{3}$, 0.1-0.2\% $\% \mathrm{Gd}_{2} \mathrm{O}_{3}$ and up to $5 \% \mathrm{SiO}_{2}$-based bonding agents.

Technology for the two-stage industrial production of ceramic OSM was also developed. The OSM is manufactured as triangular plates (Fig. 2).

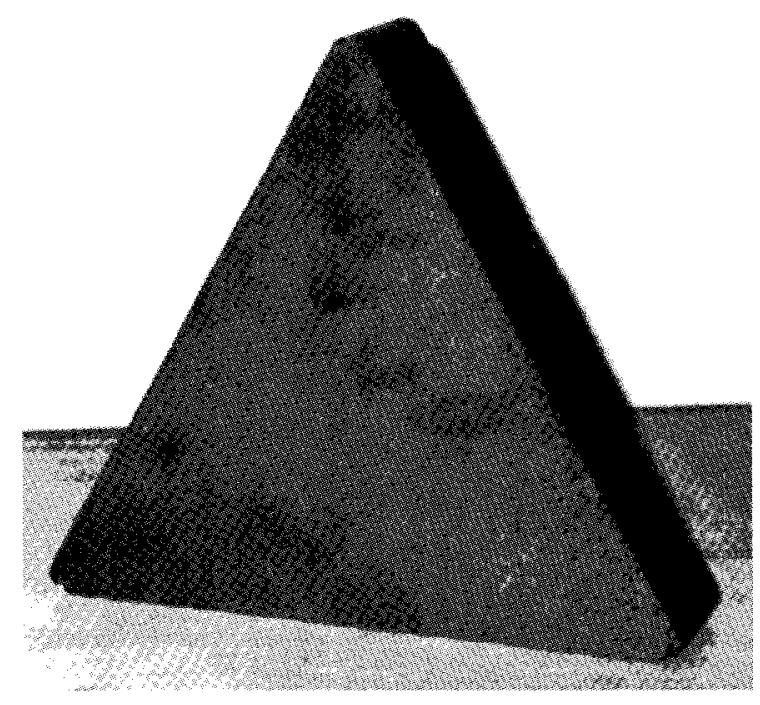

Fig. 2. OSM Block

The importance of the melt immobilization issue in the general context of VVER-1000 safety, novelty of solutions and the unprecedented crucible-type catcher design stipulate strict requirements to the justification of the new design solutions.

The first crucible-type core catcher for Tyanvan NPP was developed by a consortium of Russian research institutes and organizations.

NITI -

Catcher concept, experimental and numerical studies of thermophysical and physicochemical phenomena using the prototypic corium melts, integrated numerical modeling of phenomena occurring in the catcher, and efficiency analysis of the catcher.

$\mathrm{SPb}$ AEP -

NPP design and the general configuration of the severe accident management systems, coordination of the catcher development activities, preparation of the input data inventory and terms of reference, catcher combination with other safety systems.

PKF of ROSENERGOATOM Concern -

Detailed design of the crucible-type core catcher.

RRC "Kurchatov Institute"-

Numerical determination of the initial data for corium entering the core catcher for different severe accident scenarios; participation in the development of oxidic sacrificial materials, experimental studies of physicochemical and themophysical behavior of the prototypic corium.

ISCh RAS -

Development of ceramic sacrificial materials and technology for their production; participation in the 
investigation of physicochemical behavior of the prototypic corium.

$\mathrm{SPb}$ GTI (TU) -

Development of concrete protective and sacrificial materials.

IBRAE RAS -

Numerical determination of the input data for corium entering the core catcher from the reactor under different reference scenarios.

$\mathrm{SPb}$ ETU -

Participation in experimental studies of physicochemical phenomena in the prototypic corium.

IPPE -

Experimental studies of external catcher cooling thermohydraulics.

The activities performed in studying the catcher performance and SM behavior can be grouped as follows:

- experimental and numerical studies of local physicochemical and thermophysical phenomena in the crucible-type core catcher;

- integrated numerical modeling of in-catcher phenomena and justification of SAM efficiency.

\section{EXPERIMENTAL AND ANALYTICAL STUDIES OF LOCAL PHYSICOCHEMICAL AND THERMOPHYSICAL PHENOMENA IN THE CRUCIBLE-TYPE CORE CATCHER}

Separate effects arising during prototypic corium interaction with the core catcher materials were investigated in the facilities of the RASPLAV platform at NITI, where the technology of induction melting in a cold crucible was used; in the experimental facilities at the RRC "Kurchatov Institute, where different methods of melt heating and retention were tested; and finally in the experimental setups of ISCh RAS, mostly used for the phase diagram studies.

Among the RRC "Kurchatov Institute" experimental facilities we should separately mention a large-scale facility, RASPLAV-AW-200, used for studying physicochemical processes in the prototypic molten corium, a series of test facilities for studying melt thermophysical characteristics, and a "Korpus" setup for studying kinetics of contact interaction between solidified core melt and OSM.

Table 1 lists the main characteristics of NITI facilities.

The aforementioned experimental facilities are equipped with modern measurement systems and control and diagnostics techniques, including a number of original methods having no analogues in practice, which provide unique experimental data in the high-temperature domain of phase diagrams, where the conventional techniques are not feasible. These new methods include, for example, visual polythermal analysis in a cold crucible (VPA IMCC) and in Galakhov microfurnace.

An essential research activity important for acquiring insight into the mechanisms of high-temperature phenomena and correct interpretation of experimental data is the post-test physicochemical analysis of samples and specimens of crystallized corium and the interaction zone. The following methods of physicochemical analysis were used: XRF and XRD, optical and electron microscopy with micro XRF (SEM/EDX), mass spectrometry with inductively coupled plasma (ICP MS) and spark source

Table 1. Technical Characteristics of Experimental Facilities of the RASPLAV Platform

\begin{tabular}{|c|c|c|c|c|}
\hline \multirow{2}{*}{ Characteristics } & \multicolumn{4}{|c|}{ Experimental facility } \\
\hline & RASPLAV-2 & RASPLAV-2/C & RASPLAV-3 & RASPLAV-4 \\
\hline Melt production method & \multicolumn{4}{|c|}{ Induction melting in a cold crucible (IMCC) } \\
\hline Installed power, kWA & \multicolumn{2}{|c|}{250} & \multicolumn{2}{|c|}{100} \\
\hline Heating frequency, $\mathrm{MHz}$ & 1.76 & 1.76 & $0.066-0.12$ & 5.22 \\
\hline Mass of melt in the crucible, $\mathrm{kg}$ & Up to 5 & Up to 10 & \multicolumn{2}{|c|}{ Up to 2} \\
\hline Melt temperature, ${ }^{\circ} \mathrm{C}$ & \multicolumn{4}{|c|}{ Up to 3200} \\
\hline Above-melt atmosphere & $\begin{array}{l}\text { Air, nitrogen, helium, } \\
\text { argon, steam and their } \\
\text { mixtures }\end{array}$ & Air & \multicolumn{2}{|c|}{ Air, nitrogen, helium, argon } \\
\hline Melt composition & \multicolumn{2}{|c|}{ Oxidized in-vessel corium } & $\begin{array}{c}\text { Suboxidized melt and } \\
\text { steel }\end{array}$ & $\begin{array}{l}\text { Oxidized ex-vessel } \\
\text { corium }\end{array}$ \\
\hline $\begin{array}{l}\text { Possible manipulations with } \\
\text { melt }\end{array}$ & Ingot quenching & Melt pouring & \multicolumn{2}{|c|}{ Ingot quenching } \\
\hline
\end{tabular}


(SS MS), atomic absorption spectrometry (AAS), chromatography, and chemical analyses of dissolved samples using different methodologies.

The combination of the above-mentioned methods enables reliable identification of chemical, phase, and structural transformations of the sacrificial material during its interaction with the core melt. The experimental studies of thermophysical phenomena in the catcher cooling system were conducted using large-scale experimental facilities of NITI and FEI.

A list of completed experimental studies and their objectives, a brief description of results, and a list of references are given in Table 2.
The numerical modeling of local physicochemical and neutron-physics phenomena was performed with GEMINI thermodynamical code with the NUCLEA database and IVTANTHERMO database and with the SAPFIR-VVR95 and SAPFIR-MMK neutron physics codes [47].

GEMINI code with updated NUCLEA and IVTANTHERMO databases was used for determining phase diagrams and heat of chemical reactions, phase transitions, and thermal capacity of reacting components.

SAPFIR-VVR95 and SAPFIR-MMK codes [47] were used for determining the subcriticality of the solidified melt. Multivariant calculations aimed at finding a composition with the best multiplying properties were

Table 2. List of Experimental Studies of Local Processes for the Validation of the Crucible-type Catcher for WER-1000

\begin{tabular}{|c|c|c|c|c|}
\hline$\#$ & Study & Research objective & Publication & Note \\
\hline 1 & $\begin{array}{l}\text { Phase diagrams of multi- } \\
\text { component corium systems and } \\
\text { products of its interaction with } \\
\text { the core catcher materials }\end{array}$ & $\begin{array}{l}\text { Determine: concentration curves of liquidus } \\
\text { and solidus temperatures; coordinates of eutectic } \\
\text { and other characteristic points; solubility limits } \\
\text { of components in solid solutions; compositions } \\
\text { of coexisting liquids in the miscibility gap. } \\
\text { Use: for database update and verification of } \\
\text { thermodynamical codes applied for justification } \\
\text { of the core catcher efficiency. }\end{array}$ & $\begin{array}{l}{[19],[20],[21]} \\
{[22],[23],[24]}\end{array}$ & $\begin{array}{l}\text { Partially within } \\
\text { the ISTC } \\
\text { projects } \\
\text { CORPHAD, } \\
\text { PRECOS }\end{array}$ \\
\hline 2 & $\begin{array}{l}\text { Interaction of oxidic and } \\
\text { metallic melts with OSM }\end{array}$ & $\begin{array}{l}\text { Determine: interaction kinetics and mechanism. } \\
\text { Develop: model and correlation for calculating } \\
\text { interaction kinetics }\end{array}$ & $\begin{array}{c}{[25],[26],[27]} \\
{[28],[29]}\end{array}$ & \\
\hline 3 & $\begin{array}{l}\text { Interaction of suboxidized core } \\
\text { catcher with molten steel }\end{array}$ & $\begin{array}{l}\text { Determine: partitioning of } \mathrm{U}, \mathrm{Zr} \text { and fission } \\
\text { products between metallic and oxidic melts for } \\
\text { different compositions and mass ratios of corium } \\
\text { and steel. }\end{array}$ & {$[30],[31]$} & $\begin{array}{l}\text { Partially within } \\
\text { the OECD/ } \\
\text { MASCA } \\
\text { project }\end{array}$ \\
\hline 4 & $\begin{array}{l}\text { Interaction of core melt with } \\
\text { water-cooled steel vessel wall }\end{array}$ & $\begin{array}{l}\text { Determine: interaction mechanism and kinetics } \\
\text { depending on melt composition, its oxidation } \\
\text { degree, atmosphere (neutral, oxidizing), } \\
\text { temperature on the interaction interface. } \\
\text { Develop: correlations for calculating vessel steel } \\
\text { corrosion rates. }\end{array}$ & $\begin{array}{c}{[32],[33],[34],} \\
{[35],[36],[37],} \\
{[38],[39]}\end{array}$ & $\begin{array}{l}\text { Partially within } \\
\text { the ISTC } \\
\text { METCOR, } \\
\text { METCOR-P }\end{array}$ \\
\hline 5 & $\begin{array}{l}\text { Phenomena taking place when } \\
\text { water is supplied on top of } \\
\text { oxidic melt }\end{array}$ & $\begin{array}{l}\text { Determine: pattern of boiling, heat transfer } \\
\text { intensity at boiling, gas-aerosol release, } \\
\text { correlation for calculating heat transfer. }\end{array}$ & [40] & \\
\hline 6 & $\begin{array}{l}\text { Phenomena taking place when } \\
\text { water is supplied on top of } \\
\text { molten stcel }\end{array}$ & $\begin{array}{l}\text { Determine: pattern of boiling, formation of } \\
\text { oxidic crust, hydrogen release. }\end{array}$ & {$[41]$} & \\
\hline
\end{tabular}




\begin{tabular}{|c|c|c|c|c|}
\hline 7 & $\begin{array}{l}\text { Aerosol and FP release from } \\
\text { corium molten pool }\end{array}$ & $\begin{array}{l}\text { Determine: volatilization kinetics of melt } \\
\text { components and fission product simulants vs. } \\
\text { temperature. }\end{array}$ & $\begin{array}{c}{[42],[43],[44],} \\
{[45]}\end{array}$ & $\begin{array}{l}\text { Partially within } \\
\text { the ISTC } \\
\text { EVAN project }\end{array}$ \\
\hline 8 & $\begin{array}{l}\text { Melt oxidation when neutral } \\
\text { atmosphere is replaced with } \\
\text { oxidizing atmosphere }\end{array}$ & $\begin{array}{l}\text { Determine: melt oxidation kinetics; temperature } \\
\text { effect; oxidation influence on the pool } \\
\text { macrostructure and release of FP/aerosols. }\end{array}$ & \multirow{2}{*}{ - } & \\
\hline 9 & $\begin{array}{l}\text { Ablation of thermal protection } \\
\text { screens caused by the melt } \\
\text { surface radiation }\end{array}$ & $\begin{array}{l}\text { Determine: ablation kinetics and mechanism of } \\
\text { the thermal protection screen of the catcher. }\end{array}$ & & \\
\hline 10 & $\begin{array}{l}\text { Critical heat fluxes on the long } \\
\text { vertical surface and concave } \\
\text { downward surfaces, which } \\
\text { model the catcher vessel } \\
\text { geometry }\end{array}$ & $\begin{array}{l}\text { Determine: critical heat flux values depending } \\
\text { on the angle of slope of the catcher bottom and } \\
\text { circulation speed. } \\
\text { Choose: optimal angle of slope } \\
\text { Develop: critical heat flux correlation. }\end{array}$ & {$[13],[46]$} & \\
\hline
\end{tabular}

carried out used the SAPFIR-BBR95code, whereby the neutron-physical characteristics were determined under a broad variation of multiplying media parameters. The subcriticality was evaluated using the Monte-Carlo method and SAPFIR-MMK code in a 26-group approximation. The 26-group constants were calculated for each of the corium cells in the core catcher using the SAPFIR-VVR95 code. For the reference composition and mass of SM having 0.1-0.2 mass $\% \mathrm{Gd}_{2} \mathrm{O}_{3}$ and corium masses referring to Tyanvan NPP with VVER-1000 it was found that the required subcriticality $\left(\mathrm{K}_{\mathrm{cf}}<0.9\right)$ is provided even by cooling of corium with unborated cold water for any of the structural options (porosity and water/uranium ratio).

Dependences and correlations developed during the separate-effect studies of other local phenomena, as well as a number of known correlations, were used in the CORCAT code, which models thermal and physicochemical processes of the molten pool formation and retention in the core catcher.

\section{MOLTEN POOL FORMATION IN THE CRUCIBLE- TYPE CORE CATCHER AND EFFICIENCY JUSTIFICATION}

The integrity of the core catcher vessel at all stages of the accident progression is an indispensable condition of catcher operation. It depends on the vessel wall temperature and stress-and-strain condition, which, in turn, almost completely depends on the vessel heat loads. The reduction of the corium heat load on the vessel wall is achieved by complex engineering and management measures, which are explained briefly in [8]. The current paper addresses the molten pool formation, the dynamics of which produces a considerable influence on the pattern of the aforementioned heat loads and parameters determining the catcher vessel integrity.

\subsection{Melt Relocation into the Catcher}

Melt relocation into the catcher is preceded by formation of a molten pool in the lower head. Its specific properties are dependent on the accident scenario, reactor design, and power plant unit in general, including the safety systems. The core melt relocates into the catcher after the reactor pressure vessel (RPV) failure. Generally, the melt consists of suboxidized corium and steel, and is characterized by the mass, composition and temperature, and relocation start time and sequence.

Analysis of different scenarios of a severe accident at a NPP with VVER-1000 performed using the RATEGSVECHA-GEFEST system code $[48,49]$ provided some general sequences of the core melt progression into the catcher. In the most probable scenarios of accident sequence in VVER-1000 the metallic melt is the first entity to enter the catcher. It mostly consists of stainless steel of the invessel structures and is enriched by uranium and zirconium. Depending on the scenario, the steel mass of this first portion can vary within $30-60 \%$ of the total steel mass entering the catcher. This melt ingress occurs within a short period of time, and thus outburst release mode is assumed for the analysis. We should note that the temperature of molten steel is very high-higher than its 


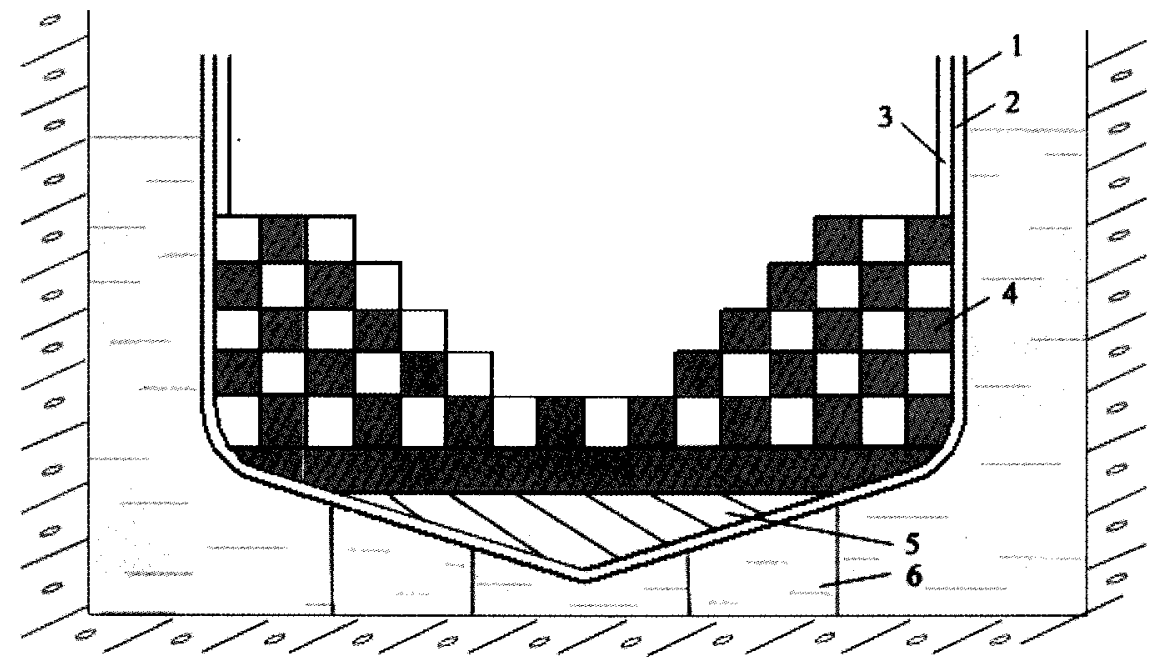

Fig. 3. Simplified Schematics of the Core Catcher

(1 - Vessel; 2 - Basket; 3 - Thermal Protection Screen; 4 - OSM and SSM; 5 - Sacrificial Concrete; 6 - Support)

melting temperature by several hundreds degrees-and this presents a potential hazard in terms of peak heat loads on the water-cooled vessel.

The next melt relocation stage (starting after a certain period of time) lasts longer, and the initial melt flow rate is gradually reduced. At this stage a melt release hole is produced by the vessel melting in the zone adjacent to the pool surface. The melt release zone shifts downward and causes the melt surface level to lower. The melt composition comprises $\mathrm{UO}_{2}, \mathrm{ZrO}_{2}, \mathrm{Zr}$, and steel. The temperature of oxidic melt is about 200-300 $\mathrm{C}$ above the liquidus temperature and the $\mathrm{Zr}$ oxidation index can vary within $40 \div 70 \%$. As a result, the catcher receives nearly all fuel and $\mathrm{Zr}$ from the core, and about $100 \mathrm{t}$ of stainless and vessel steel.

\subsection{Phenomena Influencing the Molten Pool Formation}

Fig. 3 shows the schematics of the catcher vessel and in-vessel structures. In discussing the conditions of molten pool formation in the catcher we should note that the SM configuration as a large-cell structure does not prevent melt spreading. The first inflowing mass of molten steel fills the free space in the catcher bottom. During the initial stage the melt does not contact the catcher vessel, which is protected by a steel basket (internal vessel). This steel, which is a part of the SSM, has maximum thickness in comparison with the other components. For this reason, the basket is the last component to melt and allow the melt to contact the catcher vessel. The main function of the SSM is to reduce the temperature of the relocating melt during interaction with it and to reduce the peak thermal load at the first contact of molten steel with the water-cooled catcher wall.
Together with the SSM, the sacrificial materials also include the OSM. The choice, properties, and functions of the OSM are explained in Section 2 of this paper. The primary function of the OSM is to change the composition and properties of the interacting oxidic melt. The temperature at the start of the intensive exothermal chemical interaction with $\mathrm{Zr}$-bearing steel melt is approximately $1800^{\circ} \mathrm{C}$ [29] (OSM liquidus temperature being $\sim 1700^{\circ} \mathrm{C}$ ). For this reason, if the metallic melt temperature is below $1800^{\circ} \mathrm{C}$, the interaction results in slow heating of the OSM and $\mathrm{Fe}_{2} \mathrm{O}_{3}$ decomposition into lower oxides.

In this way, the first-to-relocate molten steel is cooled while the SSM is heated and melts. During the time window before the relocation of the second portion (the remaining melt) the molten steel comes in contact with the catcher walls and solidifies on them. The OSM blocks are partially placed within the zone occupied by the first portion of the metallic melt. After the steel structures, which fix the blocks, are melted, they float to form a surface layer, which is partially restricted by the still intact in-vessel structures. The compact "bottom" layer of OSM, which is placed above the catcher concrete in the conical bottom part of the basket, also remains largely undamaged.

In the beginning of the second relocation stage, the suboxidized corium $\mathrm{UO}_{2}-\mathrm{ZrO}_{2}-\mathrm{Zr}$ (oxidic melt), being heavier than the steel melt, ingresses the bottom part of the free catcher space, forcing the molten steel (without its solidified fraction) upward, where it mixes with molten steel coming with the second portion from the RPV. The performed experimental studies on the interaction between suboxidized molten corium and OSM [26] have demonstrated that the exothermal chemical reaction of $\mathrm{Fe}_{2} \mathrm{O}_{3}$ with $\mathrm{Zr}$, which follows the principles of liquid-phase burning, causes fast OSM liquification and dissolution in oxidic 
corium melt, which continues nearly up to the complete $\mathrm{Zr}$ oxidation. Note that the released heat of chemical reactions is primarily spent not on the melt heatup, but on maintaining a high speed of interaction up to nearly complete $\mathrm{Zr}$ oxidation. Further interaction of the fully oxidized corium melt and OSM combined with the freeconvection heat exchange results in a dramatic slowingdown of the OSM melting.

If SSM remains in the oxidic corium zone, it melts and mixes with molten steel (the temperature of oxidic melt decreases during this process). The same happens to Fe generated by the above-mentioned reaction. The oxidic melt starts to solidify on the internal catcher surfaces or on the solidified steel. During OSM melting, $\mathrm{Al}_{2} \mathrm{O}_{3}$, and, after $\mathrm{Zr}$ oxidation, $\mathrm{FeO}\left(\mathrm{Fe}_{3} \mathrm{O}_{4}\right)$ as well are mixed with the oxidic melt and reduce its density. When the oxide melt density becomes lower than that of the molten steel, the inversion of melt layers occurs and molten steel relocates to the bottom of the corium pool, i.e. to its final position.

After the inversion process the flow rate of the second core melt portion drops considerably in comparison with its initial value. Its oxidic components mix with the oxidic melt layer, and the heavier metallic part proceeds to the bottom steel melt. As the pool level rises and more SM materials come in contact with the melt, the above-described cycle of melt interaction with the SM and catcher vessel wall is repeated.

Radiation from the melt pool surface during its evolution is partially blocked by the overlying SM layers. After their melt-down, the radiation is absorbed by the thermal insulation screens that protect the structures of the concrete pit and catcher top. After a design time delay, supply of the cooling water on top of the pool is initiated. Afterwards, heat removal from the oxidic pool surface takes place in the film boiling regime, which has been studied previously in the modeled conditions [40].

As the decay heat goes down, the melt solidifies. The first to crystallize is the steel layer, as the decay heat in it is approximately one order of magnitude lower than in the oxidic melt due to the character of FP partitioning between oxidic and metallic melts $[30,45]$.

\subsubsection{Modeling}

The molten pool formation and heat loads on the catcher vessel were modeled using the CORCAT code. Equations of mass and energy conservation are solved in the approximation of a model with lumped parameters for the oxidic and metallic parts of the melt. Well-known correlations on free-convention heat transfer activated by internal heat and a temperature gradient $[50,51]$ are used as closure equations. The suboxidized oxidic melt interaction with the OSM was calculated using the model described in [26]. Liquidus and solidus temperatures of the oxidic melt are calculated using the GEMINI2 code and related NUCLEA database. Thermophysical properties were mostly determined using the data of [5255]. The non-stationary heat conductivity in the walls of the catcher basket and vessel, as well as in the crust formed on the pool surface and vessel wall, is modeled in a 1D approximation taking into account melting/solidification of materials.

Calculations were made for all accident reference scenarios in order to optimize the masses of OSM and SSM and their distribution in the catcher vessel. Modeling of the catcher with anticipated SM masses and mass distributions was carried out in order to check the immobilization efficiency.

As an example we can apply the calculations for one of the basic reference scenarios for VVER-1000, which were made for a catcher vessel with an internal diameter of $5 \mathrm{~m}$ and a cylindrical wall thickness of $60 \mathrm{~mm}$. The conical bottom of the vessel is filled with SM. As mentioned above, the cylindrical part has SM arranged in a honeycomb structure (Fig. 3), where the mass of OSM is $40 \mathrm{t}$ and that of SSM is $-50 \mathrm{t}$. The melt relocation scenario has the following parameters. The first part of the melt relocates into the catcher approximately $2.3 \mathrm{hr}$ after the accident start time. This melt release includes $54 t$ of steel and $6 t$ of Zr. After approximately $15 \mathrm{~min}$, the second relocation stage starts with an outburst of the molten core into the catcher. This initial melt has the following composition:

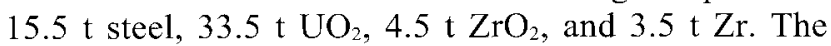
remaining part of the melt relocates into the catcher in 45 min, at a gradually reducing flow rate. The total mass of the secondary released melt consists of: $34 \mathrm{t}$ of steel, $80 \mathrm{t}$ of $\mathrm{UO}_{2}, 11 \mathrm{t}$ of $\mathrm{ZrO}_{2}$, and $8 \mathrm{t}$ of $\mathrm{Zr}$. The temperature of the molten metal is $2000^{\circ} \mathrm{C}$, while that of the oxidic melt is $2800^{\circ} \mathrm{C}$. Figs. $4-8$ show the history of the main parameters during the molten pool formation.

The first portion of molten steel quickly cools down to a level slightly exceeding the melting temperature (Fig. 4). After $140 \mathrm{~s}$ from the relocation, the basket melts down and the melt releases to the catcher wall. During the period before the second relocation stage, the thickness of steel solidified on the catcher vessel walls reaches 44 mm (Fig. 5). Immediately after the second portion enters the catcher it starts to interact with OSM. It first bursts in and forces the molten steel upward. During the interaction of suboxidized oxidic melt with the OSM, the melt density decreases and in approximately $80 \mathrm{~s}$ it becomes lower than that of molten steel (Fig. 6), leading to inversion of the melt layers. Before the inversion, only a part of the SSM had time to dissolve in the steel melt joined by the steel from the second portion, and the melt had no time to progress up to the vessel wall.

The continued ingress of the second melt portion results in an increase of corium pool depth (Fig. 7) and a gradual release of oxides and steel on certain parts of the vessel walls. During this long period of time the temperature of the oxidic melt reaches a steady-state condition. This is accompanied by a reduction of the liquidus temperature 
caused by the melt dissolution with iron and aluminum oxides. Water is supplied into the catcher $40 \mathrm{~min}$ after the melt relocation. As the decay heat goes down, the melt temperature decreases.

Maximum heat loads on the reactor vessel are determined by the non-stationary heat conductivity when

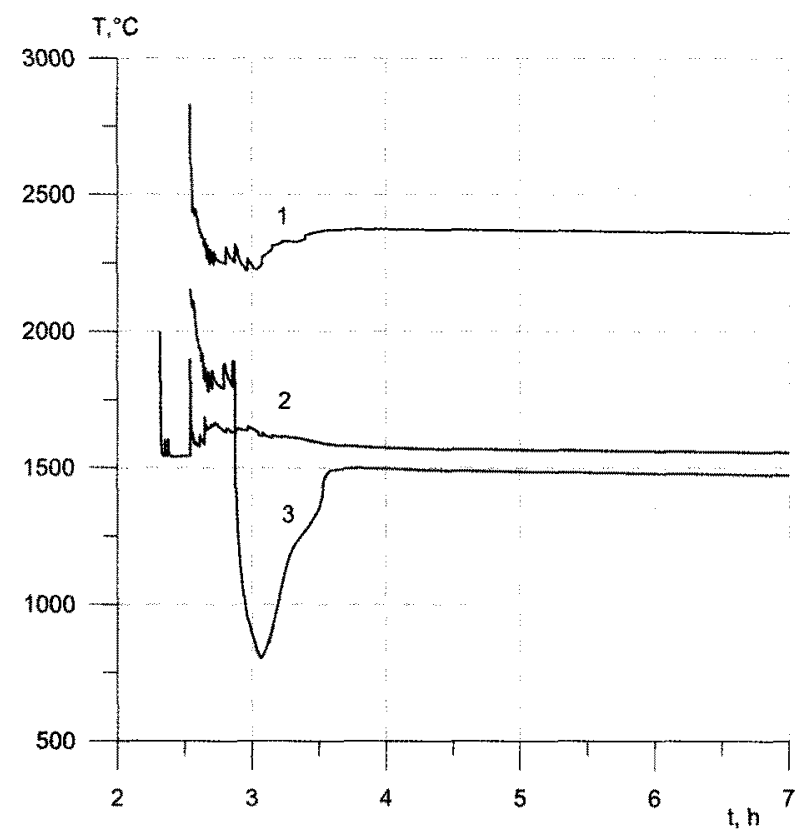

Fig. 4. Melt Temperature (1 - Oxides; 2 - Steel; 3 - Crust Surface)

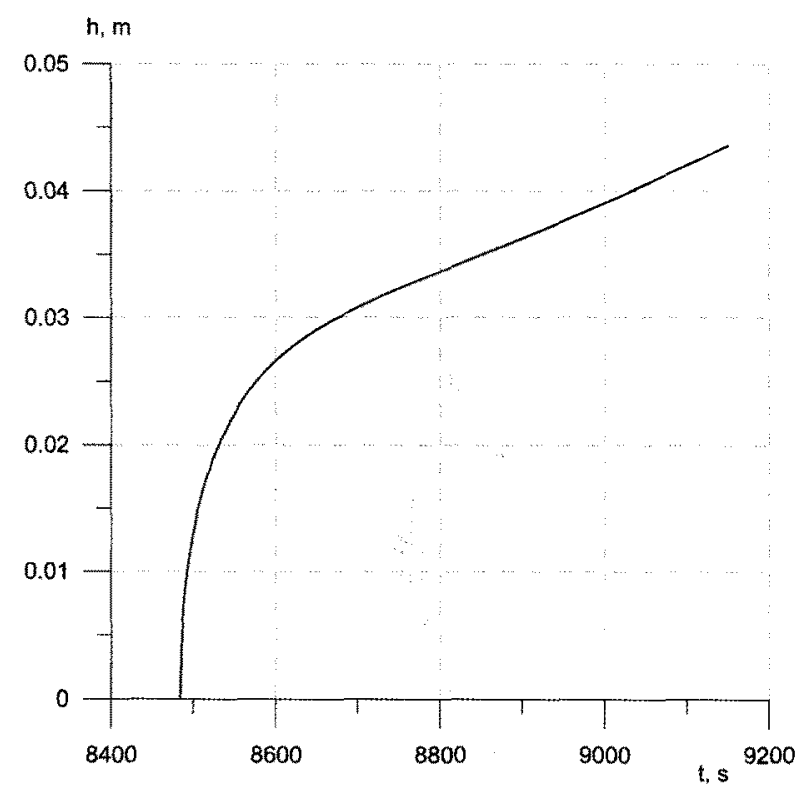

Fig. 5. Thickness of Crystallized Steel Layer on the Vessel Surface the melt comes into contact with the vessel walls. Fig. 8 shows the dynamics of the heat flux on the external watercooled surface of the different vessel parts in accordance

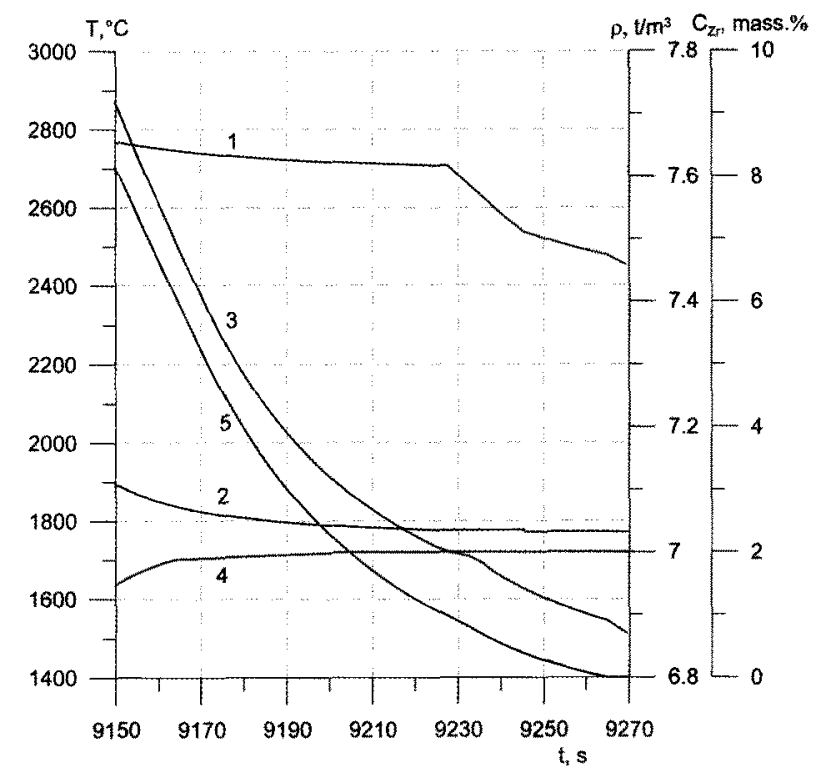

Fig. 6. Evolution of Melt Parameters in the Beginning of the Second Relocation Stage

(1 - Temperature of Oxidic Melt; 2 - Temperature of Steel Melt; 3 -Density of Oxidic Melt; 4 - Density of Steel Melt; 5 - Zr Concentration in Oxidic Melt)

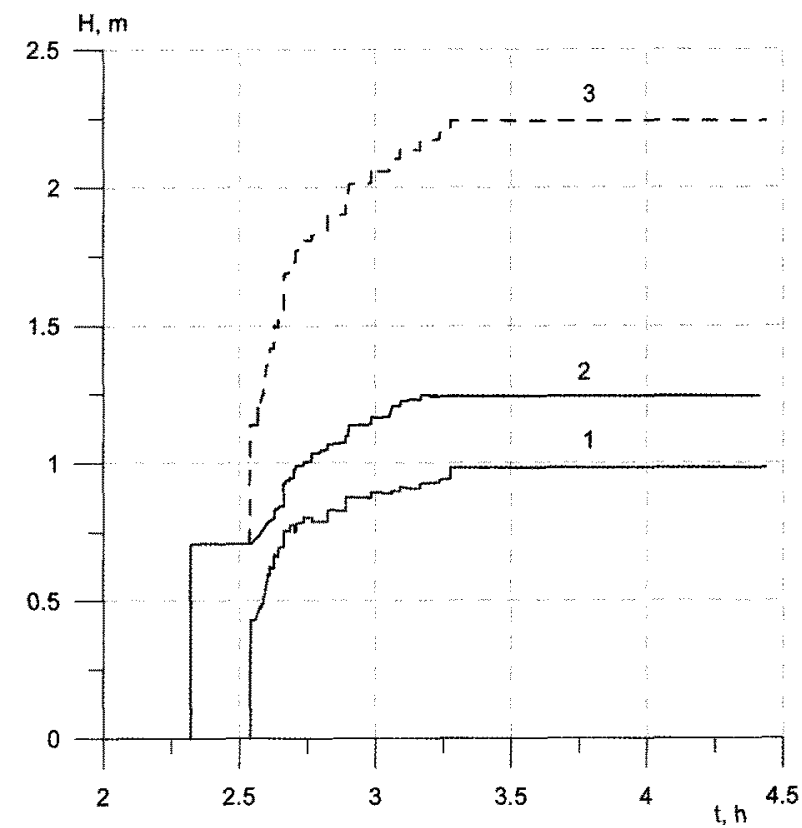

Fig. 7. Pool Depth and Layer Thicknesses (1 - Oxides; 2 - Steel; 3 - Pool Depth) 
with accepted vertical discretization. Following a conservative approach, it was assumed that if the steel melt is crystallized on the crust of previously crystallized oxides, the latter can be disregarded on the assumption of its possible cracking and separation from the strained vessel wall. Maximum values of the heat flux are reached when molten steel touches the wall in the lower part of the vessel. They are about $0.65 \mathrm{MW} / \mathrm{m}^{2}$ and decrease as the layer of frozen steel becomes thicker. In the zone of the oxidic part of the molten pool, the maximum value of heat flux is not higher than $0.45 \mathrm{MW} / \mathrm{m}^{2}$ due to the low (in comparison with steel) heat conductivity of the oxidic crust crystallized on the wall. The critical heat flux upon the boiling of a large volume of cooling water on the vertical surface at the minimal pressure in the containment of $0.2 \mathrm{MPa}$ is $1.54 \mathrm{MW} / \mathrm{m}^{2}$ [46]. This considerably exceeds the calculated heat fluxes to the cooling water providing a more than double DNB margin.

An analysis of the thermomechanical stress on the vessel was made using the ANSYS code. The calculations were made in an elastic-plastic formulation for an axisymmetrical model of the core catcher. The strength calculations were preceded by calculation of the vessel temperature conditions. The heat flux density distribution vs. time and across the height of the internal surface of the vessel was assigned using the molten pool formation model.

The calculated distribution of deformation intensities

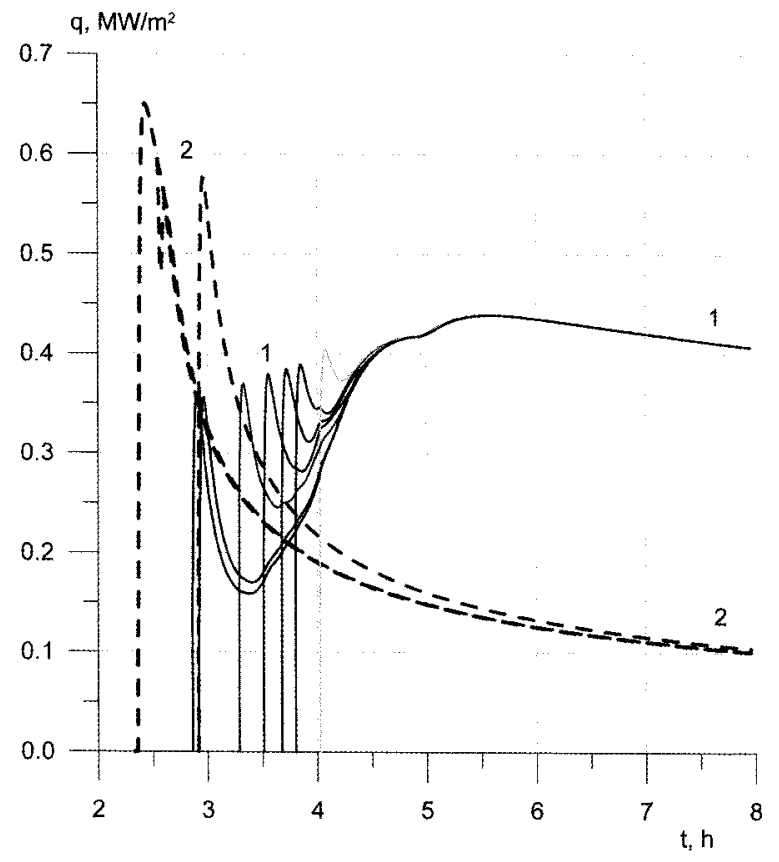

Fig. 8. Heat Flux at Different Elevations of the Vessel External Surface ( 1 - in Different Locations in the Zone of Oxides; 2 - in Different Locations in the Zone of Steel) in the most-strained cross section of the vessel wall (where cylindrical configuration changes into the elliptical one, Fig. 3) is shown in Fig. 9. The maximum intensity of plastic deformations is below 0.08 , which does not lead to vessel failure (the relative steel lengthening/stretching being taken into account).

In a conservative approach of a severe accident combined with an earthquake, consequences that should be considered include molten steel impact on the conical bottom of the core catcher, having a horizontal angle of approximately $15^{\circ}$. This is hypothetically probable in the case of OSM concrete flaking-off from the steel wall in seismic conditions. Note that the thickness of the bottom is as much as $100 \mathrm{~mm}$ larger in comparison with the cylindrical walls. Because of this, the maximum magnitude of heat flux density on the external surface of the bottom $\left(0.35 \mathrm{MW} / \mathrm{m}^{2}\right)$ is much smaller than that on the side surface. In this configuration, the value of critical heat flux is also lower $\left(\approx 0.6 \mathrm{MW} / \mathrm{m}^{2}\right)$ [13]. However, while the DNB margin on the conical surface is slightly smaller than on the vertical surface, it is still quite considerable.

It should be noted that for all severe accident scenarios considered in the safety analysis the values of key parameters influencing the margin to departure from nucleate boiling and to failure are similar to the values of the above example.

In principle, dynamic loads can present a threat to the catcher vessel integrity. They include loads produced by large-mass dropped debris and melt jets, and by the development of explosive processes.

The largest potential debris, which, in principle, can produce a shock impact on the catcher, would be the tornoff reactor vessel bottom. Even in the case of this lowprobability event, the catcher design foresees measures

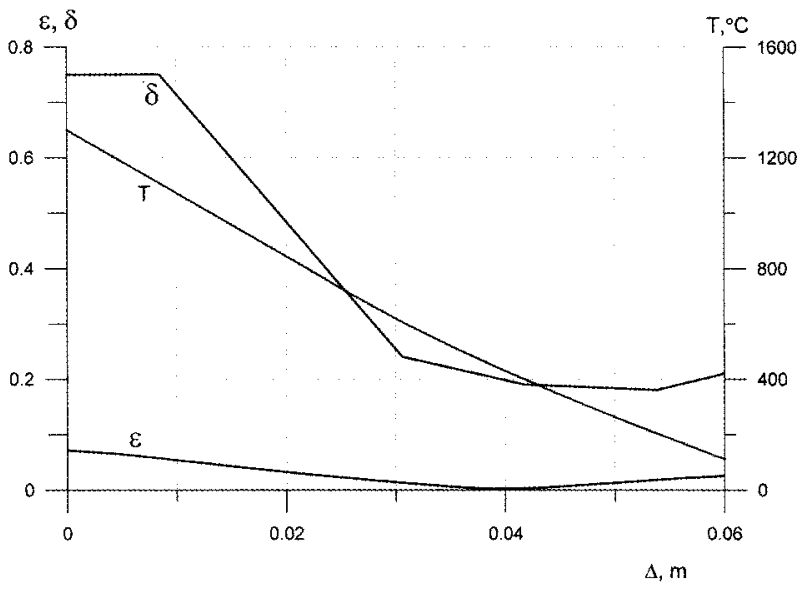

Fig. 9. Distribution of Plastic Deformation Intensity $(\varepsilon)$, Ultimate Elongation $(\delta)$ and Temperature Profile $(T)$ Versus Wall Thickness $(\Delta)$ 
mitigating this kind of impact [9]. The reactor vessel bottom undergoing plastic deformation (before the breakoff) is kept in place by the vertical ribs of the supporting lower plate (3, Fig. 1), their bottom-facing surfaces fitting the RPV shape. In the case of an insufficiently damped impact, the lower plate, on which the melt flows, transfers the shock to the massive cantilever girder (4, Fig 1). This girder is not destroyed even in the case of vessel bottom break-off under conditions of a maximum possible internal circuit pressure of 1.0 MPa.

The shock load on the catcher vessel caused by other hard debris and melt jets is eliminated by the damping properties of the basket and the honeycomb SM structure.

Steam explosions in the core catcher, which can be caused by the melt-water interaction, are excluded by the air tightness of the catcher vessel and drainage of water, which can fill the catcher before the melt. The corium melt flooding that occurs before cessation of the core melt relocation cannot cause steam explosions, because the corium flow rate at that time is insignificant and the high compressibility of the boiling steam-gas mixture does not create conditions for shock waves contributing to steam explosion. Water supply on top of the molten pool does not cause steam explosions, because a) water is supplied as a flowing film, not as a jet, and b) by the supply time water contacts the oxidic melt, because the inversion of the oxidic and metallic layers has taken place prior to this. It has been proven that steam explosions are not possible in such conditions [40].

Detonation of hydrogen generated in the catcher by steam-metallic reactions shortly before the melt inversion cannot take place due to its small concentration

Therefore, strong dynamic loads on the core vessel are either not physically possible or present no hazard. Therefore, prevention of RPV melting-through (guaranteed by DNB margin) and elimination of RPV failure (guaranteed by mechanical strength margin) provides corium localization and cooling efficiency at all studied reference scenarios of a VVER-1000 severe accident under specific thermal, physicochemical, and mechanical loads induced by a corium pool. As a long period of time (several months) is required for melt crystallization to be completed in the crucible-type core catcher, the corrosion depth of the vessel wall in contact with oxidic melt was evaluated using a correlation [39]. The initial (maximum) temperature on the internal wall surface was approximately $900^{\circ} \mathrm{C}$; the temperature and the corrosion rate were decreasing vs. time with the decay heat reduction. The calculated maximum corrosion depth did not exceed $2 \mathrm{~mm}$. The corresponding change of plastic deformation intensity caused by corrosion thinning of the wall is well within the accuracy of the mechanical calculation.

The long period of complete melt immobilization in the crucible-type catcher can be regarded as a drawback of this concept. However, this disadvantage is compensated by the concept's benefits. They are:
- small area occupied by the catcher;

- slow pressure buildup in the containment due to the low melt cooling rate;

- reduced release of gases, aerosols, and fission products, low FP leaching rate due to the limited surface of corium contact with containment atmosphere and water;

- compact structure of corium ingot, which facilitates dismantling of the core catcher with corium during decontamination.

\section{CONCLUSIONS}

Comprehensive analyses and experimental studies have confirmed the efficiency of a crucible-type core catcher for the in-containment corium retention concept for NPPs with VVER-1000 reactors. The currently available engineering and management provisions within the accepted concept enable the crucible-type catcher to be considered as a universal solution, which can be incorporated into different light-water reactor designs. Modifiable dimensions and parameters of the catcher vessel, and varied SM mass, composition, and distribution inside the catcher vessel make it possible to optimize retention conditions. Furthermore, if the concrete pit has sufficient space and large cooling water capacities are available, the crucible-type core catcher can be used without limitations set by reactor unit power and design.

\section{REFERENCES}

[ 1 ] O. Kumalainen, H. Tuomisto, T.G. Theofanous, "In-vessel retention of corium of the Loviisa plant", Nucl. Eng. Design, 169, p. 109-130 (1997).

[2] T.G. Theofanous, C. Liu, S. Addition, et al., "In-vessel coolability and retention of a core melt", Nucl. Eng. Design, 169, p. 1-48 (1997).

[3] M.F. Rogov, I.V. Kukhtevich, V.B. Khabenskii, et al., "Analyzing the Corium in the Vessel of a VVER-640 Reactor in a Severe Accident with a Damaged Core", Thermal Engineering, v. 43, 11, p. 888-892 (1996).

[4] T.N. Dinh, J.P. Tu, T.G. Theofanous, "Two-Phase Natural Circulation Flow in AP-1000 In-Vessel Retention - Related ULPU-V Facility Experiments", Proc. of ICAPP'04, Paper 4242, p. 928-938, Pittsburgh, USA, June 13-17, 2004.

[5] N.T. Kolev, "SWR 1000 Severe Accident Control the Rough In-Vessel Melt Retention by External Cooling", Proc. of ICONE9, $9^{\text {th }}$ Int. Conf. on Nucl. Eng., Nice, France, April 8-12, 2001

[6] Lindholm I., Berg O., Nonbol E., "Safety against releases in severe accidents. Final Report of the Nordic Nuclear Safety Research Project RAK-2", NKS(97)FRZ. ISBN 87783-022-7, December (1997).

[ 7 ] I.V. Kukhtevich, V.V. Bezlepkin, V.S. Granovskii, et al., "The Concept of Localization of the Corium Melt in the Ex-vessel Stage of a Severe Accident at a Nuclear Power Station with a VVER-1000 Reactor", Thermal Engineering, v. 48, 9, p. 699-707 (2001). 
[ 8 ] V.G. Asmolov, S.V. Bechta, V.M. Berkovich, et al., "Crucibletype Core Catcher for VVER-1000 Reactor", Proc. of ICAPP'05, Seoul, Korea, May 15-19, 2005, Paper 5328 (2005).

[9] A.S. Sidorov, A.B. Nedorezov, M.F. Rogov, et al., "The Device for Core Melt Localization at the Tyan'van Nuclear Power Station with a VVER-1000 Reactor", Thermal Engineering, v. 48, 9, p. 707 (2001).

[10] M. Fischer, "The severe accident mitigation concept and the design measures for core melt retention of the European Pressurized Reactor (EPR)", Nucl. Eng. Design, 230, p. 169-180 (2004).

[11] Yu. A. Bezrukov, S.A. Logvinov, A.P. Onshin, "Studies of heat release from the lower reactor head in an accident with fuel meltdown", First Russian national conference on heat transfer, Moscow, v. 4, p. 19-25 (1994), (in Russian).

[12] T.G. Theofanous, S. Syri, T. Salmassi, et al., "Critical Heat Flux through Curved, Downward Facing, Thick Walls", Proc. of the Workshop on Large Molten Pool Heat Transfer, Grenoble, France, March 9-11, 1994.

[13] A.A. Sulatski, O.D. Cherny, and V.K. Efimov, "Investigation of Boiling Crisis at a Downward-Facing Inclined Surface", Proc. of the 12-th Int. Heat Transfer Conf., v.3, p. 509514, Grenoble, France, August 18-23, 2002.

[14] V.V. Gusarov, V.B. Khabenskii, S.V. Bechta, et al., "A Sacrificial Material of the Device for Localization of the Corium Melt in Off-Design Accidents at Nuclear Power Stations Equipped with VVER-1000 Reactors: the Concept of the Development, Its Substation and Implementation", Workshop on Problems of Safety at NPPS Equipped with VVER, Saint Petersburg, 12-14 September, 2000 (in Russian).

[15] V.V. Gusarov, V.I. Al'myashev, S.V. Bechta, et al., "Sacritical Materials for Safety Systems of Nuclear Power Stations: A New Class of Functional Materials", Thermal Engineering, v. 48, 9, p. 721 (2001).

[16] V.G. Asmolov, V.N. Zagriazkin, V.Yu. Vishnevskiy, et al., "Selecting Buffer Material of the Catcher to Retain Molten Corium of VVER-1000 Core", J. Atomnaya Energiya (Atomic Energy), v. 92, 1, p. 7-18 (2002), (in Russian).

[17] V.V. Gusarov, V.I. Almjashev, V.B. Khabensky, et al.,. "Physicochemical modeling and analysis of the interaction between a core melt of the nuclear reactor and a sacrificial material", Glass Physics and Chemistry, v. 31, 1, p. 53-66 (2005).

[18] V.V. Gusarov, V.I. Al'miashev, V.B. Khabensky et al., "New class of functional materials for the core catcher", Russian chemical journal, v. XIIX, 4, p. 42-53 (2005), (in Russian).

[19] S.V. Bechta, E.V. Krushinov, V.I. Almiashev et al., "Phase relations in the $\mathrm{ZrO} 2 \mathrm{FeO}$ system", J. of Nonorganic Chemistry, v. 51, 2, p. 325-331 (2006), (in Russian).

[20] V.V. Gusarov, V.I. Almjashev, V.B. Khabensky, et al., "Distribution of components between immiscible melts of a system under nonisothermal conditions", Glass Physics and Chemistry, v. 32, 6, p. 638-642 (2006).

[21] S.V. Bechta, E.V. Krushinov, V.I. Almjashev, et al., "Phase Diagram of the $\mathrm{ZrO}_{2}-\mathrm{FeO}$ System", Journal of Nuclear Materials, v. 348, 1-2, p. 114-121 (2006).

[22] S.V. Bechta, E.V. Krushinov, V.I. Almjashev, et al., "Phase transformation in the binary section of the $\mathrm{UO}_{2}-$
FeO-Fe system", Radiochemistry, v. 49, 1, p. 20-24 (2007).

[23] S.V. Bechta, E.V. Krushinov, V.I. Almjashev, et.al., "Phase Diagram of the $\mathrm{UO}_{2}-\mathrm{FeO}_{1+x}$ System", Journal of Nuclear. Materials, v. 362, p. 46-52 (2006).

[24] V.I. Almjashev, M. Barrachin, S.V. Bechta, et al., "Eutectic crystallization in the $\mathrm{FeO}_{1,5}-\mathrm{UO}_{2+x}-\mathrm{ZrO}_{2}$ system", Journal of Nuclear Materials, v. 389, No. 1, p. 52-56 (2009).

[25] A.A. Sulatsky, S.V. Bechta, V.S. Granovsky, et al., "Molten Corium Interaction with Oxidic Sacrificial Material of VVER Core Catcher", Proc. of ICAPP'05, Paper 5240, Seoul, Korea, May 15-19, 2005.

[26] V.G. Asmolov, A.A. Sulatskii, S.V. Bechta, et al., "The interaction of nuclear reactor core melt with oxide sacrificial material of localization device for a nuclear power plant with water-moderated water-cooled power reactor", High Temperature, v. 45, 1, p. 22 (2007).

[27] V.V. Gusarov, V.I. Almjashev, V.B. Khabensky, et al., "Interaction of a material based on aluminium and iron oxides with a metal melt", Russian Journal of Appjied Chemistry, v. 80, 4, p. 515-522 (2007).

[28] V.V. Gusarov, V.I. Almjashev, V.B. Khabensky, et al., "Physicochemical simulation of the combustion of materials with the total endotermal effect", Glass Physics and Chemistry, v. 33, 5, p. 492-497 (2007).

[29] S.V. Bechta, V.S. Granovsky, A.A. Sulatsky, et al., "Model of Interaction of Molten Steel with Sacrificial Material of VVER Core Catcher", Proc. of Research Workshop "Evaluation of experimental data and verification of computer codes", Sosnovy Bor, Russia, October 4-6, 2004 (in Russian).

[30] V.G. Asmolov, S.V. Bechta, V.B. Khabensky, et al., "Partitioning of $\mathrm{U}, \mathrm{Zr}$ and FP between molten oxidic and metallic corium", MASCA Seminar, Aix-en-Provence, France, June 10-11, 2004.

[31] S.V. Bechta, V.S. Granovsky, V.B. Khabensky, et al, "Corium Phase Equilibrium from MASCA, METCOR and CORPHAD Results", Nucl. Eng. Design, 238, p. 27612771 (2008).

[32] S.V. Bechta, V.B. Khabensky, S.A. Vitol, et al., "Experimental Studies of Oxidic Corium Interaction with Reactor Vessel. Steel Samples", Rasplav Seminar, Int. Meeting Centre of Science, Munich, Germany, November 14-15, 2000.

[33] S.V. Bechta, V.B. Khabensky, S.A. Vitol, et al., "Experimental Studies of Oxidic Molten Corium-Vessel Steel Interaction", Nucl. Eng. Design, 210, p. 193-224 (2001).

[34] S.V. Bechta, V.B. Khabensky, V.S. Granovsky, et al., "New Experimental Results on the Interaction of Molten Corium with Reactor Vessel Steel", Proc. of ICAPP'04, Paper 4114, p. 1072-1081, Pittsburgh, PA USA, June 1317, 2004.

[35] S.V. Bechta, V.B. Khabensky, S.A. Vitol, et al., "Corrosion of Vessel Steel during its Interaction with Molten Corium. Part 1: Experimental", Nucl. Eng. Design, 236, 1810-1829 (2006).

[36] S.V. Bechta, V.B. Khabensky, S.A. Vitol, et al., "Corrosion of Vessel Steel during its Interaction with Molten Corium. Part 2: Model Development", Nucl. Eng. Design, 236, 1362-1370 (2006).

[37] S.V. Bechta, V.S. Granovsky, V.B. Khabensky, et al., "Experimental Study of Interaction between Suboxidized Corium and Reactor Vessel Steel", Proc. of ICAPP'06, 
Paper 6054, Reno, NV USA, June 4-6, 2006.

[38] S.V. Bechta, V.S. Granovsky, V.B. Khabensky, et al., "Interaction between Molten Corium $\mathrm{UO}_{2+x}-\mathrm{ZrO}_{2}-\mathrm{FeO}_{y}$ and VVER Vessel Steel", Proc. of ICAPP'08, Paper 8052, Anaheim, CA USA, June 8-12, 2008.

[39] S.V. Bechta, V.S. Granovsky, V.B. Khabensky, et al., "VVER Vessel Steel Corrosion of Interaction with Molten Corium in Oxidizing Atmosphere", Nucl. Eng. Design, (in press), (2009).

[40] S.V. Bechta, S.A. Vitol, E.V. Krushinov, et al., "Water Boiling on the Corium Melt Surface under VVER Severe Accident Conditions", Nucl. Eng. Design, 195, p. 45-56 (2000).

[41] D.B. Lopukh, I.A Loginov, V.S. Granovskii, et al., "Experimental investigation of processes arising when flooding a steel melt", Thermal Engineering, v. 48, 9, p. 725 (2001).

[42] A.M. Beard, S.V. Bechta, C.G Benson, et al., "Late Phase Source Term Phenomena: Summary Final Report", $A E A T$, SAM-LPP-D032, July, 2003.

[43] S.V. Bechta, S.A. Vitol, E.V. Krushinov, et al., "Fission Product Release from Molten Pool: Ceramic Melt Tests", Proc. of SARJ Meeting, Tokyo, Japan, November 4-6, 1998.

[44] A.M. Beard, S.V. Bechta, C.G Benson, et al., "Late Phase Source Term Phenomena: Summary Final Report", Proc. of FISA 2003-EU Research in Reactor Safety, Luxemburg, November 10-13, 2003.

[45] S.V. Bechta, E.V. Krushinov, S.A. Vitol, et al., "Influence of corium oxidation on fission product release from molten pool", Proc. of ICAPP'09, Paper 9145, Tokyo, Japan, May 10-14, 2009.

[46] A.A. Sulatskii, O.D. Chernyi, V.K. Efimov, et al., "Burnout on the external surface of a VVER reactor vessel", Thermal
Engineering, v.45, 11, p. 913 (1998).

[47] V.G. Artemov, A.S.Ivanov, A.S. Karpov, et al., "Investigating the subcriticality of a molten core localization device using ferric- and aluminium- oxide base fillers", Thermal Engineering, v. 48, 9, p. 707 (2001).

[48] V.V. Bezlepkin, V.G. Sidorov, A.V. Lukin, et al, "Development of computer codes for the simulation of severe accidents at nuclear power stations", Thermal Engineering, v. 51, 2, p. 88 (2004).

[49] S.V. Onufrienko, I.V. Kukhtevich, V.V. Bezlepkin, et al., "Analysis of the Processes in the VVER-1000 Core under Severe Accidents with Application of Russian Integral Code RATEG/SVECHA/GEFEST", Proc. of CKTI, "Atomnoe Energomashinostroenie", v. 282, p. 89-100, CKTI, Saint Petersburg, Russia, 2002, (in Russian).

[50] U. Steinberner, H.H. Reineke, "Turbulent buoyaney convection heat transfer with internal heat sources", Proc. 6-th Int. Heat Transfer Conf., NC-21, p. 305-310, Toronto, Canada. Aug. 1978.

[51] V.A. Grigoriev and V.M. Zorin (editors), "Theoretical basics of thermal engineering. Thermal technology experiment", Reference book, M.: Energoatomizdat, 1988 (in Russian).

[52] "Light water reactor lower head failure analysis (draft)", NUREG/CR-5642, EGG-2612 (1992).

[53] I.S. Grigoriev and E.Z. Mejlikhov (editors), "Physical values". Reference book. M.: Energoatomizdat, 1991 (in Russian).

[54] Journeau C., "TG3: Physical Properties. Density Data for Liquid Corium", DEN/CAD/DTP/STH/LMA 05/06/03 ECoStar Meeting, Berlin, April, 2003.

[55] M. Barrachin, F. Defoort, "Thermophysical properties of in-vessel corium: MASCA program related results", Proc. of MASCA Seminar, Aix-en-Provance, France, 2004. 